\title{
ANALISIS KEUNTUNGAN PENGGEMUKAN SAPI POTONG KELOMPOK TANI "KEONG MAS" DESA TAMBULANGO KECAMATAN SANGKUB BOLAANG MONGONDOW UTARA (STUDI KASUS)
}

\author{
Richard J. Makkan*, Anie Makalew**, F. H. Elly** dan I. D. R. Lumenta** \\ Fakultas Peternakan Universitas Sam Ratulangi Manado, 95115.
}

\begin{abstract}
ABSTRAK
Penggemukan sapi potong kelompok tani ternak sapi "Keong Mas" merupakan usaha penggemukan sapi potong yang terletak di Desa Tambulango Kecamatan Sangkub Kabupaten Bolaang Mongondow Utara. Kelemahan dari kelompok tani "Keong Mas" yaitu belum mengetahui berapa keuntungan yang diperoleh dari usaha tersebut. Anggota kelompok beranggapan bahwa usaha ternaknya telah memperoleh keuntungan. Padahal, mereka tidak menghitung aset yang digunakan dalam usaha penggemukan sapi potong sehingga nilai investasi sangat besar. Tujuan penelitian untuk mengetahui keuntungan dan layak tidaknya usaha yang dijalankan oleh kelompok tani ternak sapi "Keong Mas". Metode penelitian yang digunakan adalah studi kasus. Analisis yang digunakan adalah analisis keuntungan dan kelayakan usaha. Hasil penelitian menunjukkan usaha penggemukan sapi potong kelompok tani ternak sapi "Keong Mas" memperoleh keuntungan sebesar Rp.7.433.750 dengan pemeliharaan 15 ekor. Biaya produksi yang dikeluarkan sebesar Rp. 97.566.250 terdiri dari biaya tetap sebesar Rp. 6.295.000 dan biaya variabel sebesar Rp. 91.271.250. Biaya kandang merupakan biaya terbesar dari total biaya tetap yaitu sekitar 42,8\%. Biaya bibit merupakan biaya terbesar dari total biaya variabel yaitu sekitar $58 \%$. Penerimaan yang diperoleh sebesar Rp.105.000.000 dari hasil penjualan 15 ekor sapi dengan harga Rp. 7.000.000 / ekor. Kesimpulannya, keuntungan usaha penggemukan sapi
\end{abstract}

\footnotetext{
*Alumni Fakultas Peternakan Unsrat

**Jurusan Sosial Ekonomi Peternakan
}

potong kelompok tani ternak sapi "Keong Mas" positif dan layak untuk dijalankan dilihat dari nilai NPV sebesar Rp. 38.795.714, IRR $38 \%$ dan net BCR sebesar 1.95 .

Kata Kunci : Penggemukan, Sapi Potong, Keuntungan, Kelayakan

\section{ABSTRACT}

\section{PROFIT ANALYSIS ON BEEF CATTLE FATTENING OF KEONG MAS FARMER GROUP AT TAMBULANGO VILLAGE, SANGKUB DISTRICT, NORTH BOLAANG MONGONDOW REGENCY (CASE STUDY).}

Beef Cattle Fattening of "Keong Mas" farmer group was located at Tombolango village, District of Sangkub, North Bolaang Mongondow regency. The problem was that the farmer group did not know to evaluate the profits as well as the beneficial farm condition. The purpose of the study was to determine the profit and feasibility of beef farm managed by "Keong Mas" farmer group. The research method was carried out as case study. The statistical analysis was conducted by the analysis of the profit and feasibility. The results showed that fattening beef cattle farmer group of "Keong Mas" gained of Rp 7,433,750,- with maintaining beef animals of 15 heads. Production costs spent in animal farm were $\mathrm{Rp}$ $97,566,250$,- consisting of a fixed cost of $\mathrm{Rp}$ 6,295,000.- and variable cost of $\mathrm{Rp}$ $91,271,250 .-$. The cost of the house pens was the largest expense of the total fixed cost whith the cost of about 42.8 percents. Calf breeding stock costs were the largest 
expense of the total variable cost with about 58 percents. Turnover obtained of Rp 105,000,000.- from sale process of 15

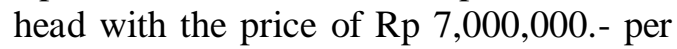
head. Based on the feasibility analysis of the fattening beef cattle of "keong Mas" farmer groups showed that this animal farm was feasible to be running with showing NPV of Rp 38,795,714.- and IRR of 38 percents and $1.95 \mathrm{Net} \mathrm{BCR}$.

Keywords : Fattening, Beef Cattle, Profit, Feasibility, Farmer group, Tabulango village.

\section{PENDAHULUAN}

Pembangunan sub sektor peternakan merupakan bagian integral dari pembangunan sektor pertanian dalam pengembangan dan peningkatan ekonomi bangsa dan negara. Pembangunan sub sektor peternakan sebagai salah satu upaya dalam pemenuhan kebutuhan protein hewani masyarakat. Upaya ini juga bertujuan untuk mensejahterakan para petani peternak dan kemampuannya dalam mendorong pertumbuhan sektor pembangunan. Salah satu usaha peternakan yang dapat dikembangkan di Indonesia adalah usaha penggemukan sapi. Penggemukan sapi di Indonesia umumnya berskala kecil sebagai usaha sampingan dan masih bersifat tradisional. Tetapi, tingkat produktivitas ternak sapi potong masih rendah yang diikuti dengan permintaan daging yang makin meningkat berdampak terhadap peningkatan volume impor sapi bakalan maupun daging (Yusran, 2004). Menurut Kiswanto et al (2004), upaya yang dapat ditempuh untuk mempercepat peningkatan produksi daging sapi di dalam negeri adalah melalui pengembangan usaha penggemukan sapi potong. Kabupaten Bolaang Mongondow Utara merupakan salah satu Kabupaten di Provinsi Sulawesi Utara. Kabupaten ini memiliki potensi sumber daya lahan untuk pengembangan usaha penggemukan sapi potong.

Hasil pra survey menunjukkan, sebagian peternak di Kecamatan Sangkub telah melakukan usaha penggemukan sapi potong dengan berhimpun didalam kelompok tani. Salah satu kelompok tani yang ada di Kecamatan Sangkub adalah "Keong Mas". Kelemahan dari kelompok tani "Keong Mas" yaitu belum pernah menghitung berapa keuntungan yang diperoleh. Anggota kelompok beranggapan bahwa usaha ternaknya telah memperoleh keuntungan. Padahal, mereka tidak menghitung aset yang digunakan dalam usaha penggemukan sapi potong sehingga nilai investasi sangat besar. Berdasarkan permasalahan tersebut maka telah dilakukan penelitian tentang keuntungan dan kelayakan 
penggemukan sapi potong di kelompok tani "keong mas" di desa Tambulango Kecamatan Sangkub Kabupaten Bolaang Mongondow Utara.

\section{MATERI DAN METODE PENELITIAN}

Penelitian ini dilaksanakan di kelompok tani ternak sapi "Keong Mas" di Desa Tambulango Kecamatan Sangkub Kabupaten Bolaang Mongondow Utara. Penelitian ini dilakukan dengan menggunakan metode studi kasus seperti yang dinyatakan Aries (2008). Sumber data yang dikumpulkan yaitu data primer dan sekunder. Data primer diperoleh melalui pengamatan langsung di lokasi penelitian, pencatatan dan wawancara dengan pengelola dengan menggunakan daftar pertanyaan yang telah disusun. Data sekunder diperoleh dari dinas dan instansi terkait.pengumpulan data dilakukan pada tanggal 20 November sampai dengan 19 Desember 2013. Jenis data yang digunakan yaitu cross section pada tahun 2012. Analisis yang digunakan ialah analisis keuntungan dan kelayakan terdiri dari NPV, IRR, net BCR. Definisi variabel dan pengukurannya adalah (i) Kelompok tani/peternak adalah himpunan atau kumpulan dari peternak yang teroganisir dan melakukan pemeliharaan ternak sapi. (ii) Usaha Penggemukan Sapi potong adalah suatu usaha peternakan yang bertujuan menjual ternak sapi siap potong. (iii) Produksi ternak sapi adalah jumlah ternak sapi yang dihasilkan pada periode satu tahun (Ekor/Tahun). (iv) Biaya Produksi adalah sejumlah biaya yang dikeluarkan dalam suatu usaha ternak (Rp/Tahun). (v) Biaya tetap (fixed cost) biaya yang selalu jumlahnya tetap dan tidak dipengaruhi oleh besar kecilnya tingkat produksi selama satu periode produksi (Rp/tahun). (vi) Biaya tidak tetap (variable cost) adalah biaya yang jumlahnya berubah-ubah sesuai dengan perubahan tingkat produksi selama satu periode produksi (Rp/tahun). (vii) Penerimaan adalah jumlah uang yang diterima peternak dari hasil penjualan ternak sapi potong (Rp/tahun). (viii) Keuntungan adalah selisih antara penerimaan dengan biaya produksi selama setahun (Rp/tahun).

\section{HASIL DAN PEMBAHASAN}

Desa Tambulango merupakan salah satu desa yang berada di Kecamatan Sangkub Kabupaten Bolaang Mongondow Utara. Di daerah ini terdapat usaha peternakan penggemukan sapi potong yang 
dikelola oleh peternak yang tergabung dalam kelompok usaha tani ternak. Penggemukan sapi potong memiliki potensi untuk dikembangkan di Kecamatan Sangkub dilihat dari kondisi iklim. Selain itu, ketersediaan lahan dan sumber daya alam. Pelaksanaaan usaha penggemukan sapi potong di Kecamatan Sangkub dilakukan oleh petani Ternak Sapi yang tergabung dalam kelompok tani. Usaha ini terbentuk atas kepentingan dan tujuan bersama dan diawali dengan modal bersama. Populasi ternak sapi potong bervariasi berdasarkan umur dan jenis kelamin. Ternak sapi potong bervariasi dari umur 1,8 tahun -2 tahun yang terdiri dari 10 ekor jantan dan 5 ekor betina.

Hasil penelitian menunjukkan lokasi kandang cukup baik. Hal ini ditunjang dari sumber pakan jerami padi yang dekat untuk konsumsi ternak sapi potong. Konstruksi kandang kuat dan tahan lama sesuai pendapat Abidin (2002). Kandang sapi potong dilengkapi juga dengan bak serta penampungan pakan dan saluran pembuangan. Tiang kandang terbuat dari kayu dan besi, beratapkan seng, serta berlantaikan semen dan kapasitas kandang sekitar 25 ekor. Menurut Prawirokusumo (2000) bahwa, kandang dapat dibuat dalam bentuk ganda atau tunggal, tergantung dari jumlah sapi yang dimiliki. Kandang tipe tunggal, penempatan sapi dilakukan pada satu baris atau satu jajaran, sementara kandang yang bertipe ganda penempatannya dilakukan pada dua jajaran yang saling berhadapan atau saling bertolak belakang. Diantara kedua jajaran tersebut biasanya dibuat jalur untuk jalan. Lantai kandang terbuat dari beton dan kemiringan lantai mencapai $4^{\mathrm{O}}$ dan kandang dapat disinari sinar matahari. Kandang juga memiliki ventilasi yang baik sehingga adanya sirkulasi udara di dalam kandang lancar, ini sesuai dengan pendapat Abidin (2002). Selokan merupakan saluran pembuangan kotoran dan air kencing. Ukuran selokan kandang disesuaikan dengan kondisi kandang dan tujuan pemeliharaan. Ukuran selokan lebar $30-40 \mathrm{~cm}$ dan kedalaman $5-10 \mathrm{~cm}$.

Hasil penelitian menunjukkan bahwa pakan yang diberikan bagi ternak sapi adalah jerami padi. Hal ini disebabkan karena jerami padi cukup tersedia, kemudian pada musim kemarau hijauan berupa rumput sangat terbatas. Menurut Suryapratama dan Santosa (2011), pada musim kemarau ketersediaan hijauan (rumput) sangat terbatas, sehingga perlu dicari 
alternatif pengganti rumput yang tersedia sepanjang tahun diantaranya jerami padi. Pakan bagi penggemukan sapi menurut Elly (2009) merupakan sarana produksi yang sangat penting bagi ternak karena berfungsi sebagai pemacu pertumbuhan. Pakan ternak sapi potong yang dianjurkan terdiri dari $60 \%$ hijauan dan $40 \%$ konsentrat. Pakan berupa hijauan segar bagi sapi dewasa umumnya diberikan sebanyak $10 \%$ dan jerami padi $2 \%-3 \%$ dari bobot badan sedangkan pakan penguat sebesar $1 \%$ - $2 \%$ (Soekardono, 2009). Berdasarkan penelitian pemberian pakan diberikan 2 kali sehari yaitu pagi dan sore hari. Pakan yang diberikan berupa jerami dan dedak padi. Pakan jerami yang diberikan rata -rata 11 $\mathrm{kg} / \mathrm{ekor} / \mathrm{hari}$ dan pemberian pakan penguat yaitu dedak padi rata - rata 5 $\mathrm{Kg} / \mathrm{ekor} / \mathrm{hari}$.

Tenaga kerja pada untuk usaha penggemukan sapi potong "Keong Mas" adalah tenaga kerja anggota kelompok yang diupah. Curahan kerja ini berbeda dengan curahan kerja pada usaha ternak sapi yang tidak dikandangkan. Curahan kerja petani peternak untuk usaha ternak sapi yang tidak dikandangkan dilakukan oleh kepala keluarga (Salendu dan Elly, 2009). Total curahan waktu tenaga kerja sesuai hasil penelitian sebesar 2,5 jam/hari dengan 2 orang pekerja. Hasil penelitian Elly (2008) menunjukkan bahwa curahan kerja pada usaha ternak sapi yang tidak dikandangkan rata-rata sebanyak 1.23 jam per hari per rumahtangga. Hasil penelitian menunjukkan bahwa curahan waktu yang terbesar adalah mencari jerami $(40 \%)$ dan sisanya sebesar $(20 \%)$. Hal ini disebabkan karena anggota kelompok harus pergi mengumpulkan dan mengangkut jerami padi di lahan pertanian sawah milik desa sekitar karena tidak semua lahan sawah yang serentak melakukan panen padi.

Kesehatan ternak merupakan salah satu faktor penting yang mempengaruhi produksi ternak termasuk produksi daging sapi. Sapi sapi potong yang dipelihara harus dilakukan vaksinasi dan sanitasi kandang untuk produksi daging yang optimal. Hasil penelitian pada usaha ternak sapi potong di Kelompok Tani Ternak sapi "Keong Mas", menunjukkan bahwa permasalahan penyakit yaitu cacing yang ada di alat pencernaan.cacingan pada ternak serin g menimbulkan dampak kerugian yang cukup besar bagi peternak. Penyakit cacingan pada ternak khususnya ternak ruminansia seperti sapi, akan menurunkan pertumbuhan berat badan hingga mencapai 20\%. Hal ini sudah 
dapat diatasi dengan diberikannya obat yang dianjurkan dari Dinas Penyuluhan Pertanian peternakan setempat baik resep obat tradisional untuk mengatasi cacingan pada ternak. Menurut Soekardono (2009), biaya produksi secara teori terdiri dari biaya tetap dan biaya variabel. Biaya tetap adalah biaya yang dikeluarkan setiap tahun yang besarnya tidak berpengaruh langsung terhadap jumlah output yang dihasilkan. Biaya tetap yang dikeluarkan sesuai hasil penelitian meliputi sewa tanah, telepon dan listrik dan penyusutan. Rincian biaya tetap dapat dilihat pada Tabel 1.

\begin{tabular}{clrr}
\multicolumn{5}{c}{ Tabel 1. Rincian Biaya Tetap Kelompok Tani Ternak Sapi "Keong Mas" } \\
\hline No & \multicolumn{1}{c}{ Uraian } & Jumlah $(\mathrm{Rp})$ & $\%$ \\
1 & Sewa Lahan & 750.000 & 11,9 \\
2 & Biaya telepon dan listrik & 1.200 .000 & 19,1 \\
3 & Biaya Penyusutan Parang & 50.000 & 0,8 \\
4 & Biaya Penyusutan Skop & 120.000 & 1,9 \\
5 & Biaya Penyusutan Cangkul & 65.000 & 1,0 \\
6 & Biaya Penyusutan Ember & 10.000 & 0,2 \\
7 & Biaya Penyusutan Kandang & 2.700 .000 & 42,8 \\
8 & Biaya Penyusutan Kendaraan(Hand & 1.300 .000 & 20,7 \\
& Traktor) & 100.000 & 1,6 \\
9 & Biaya Penyu. Gerobak Dorong & 6.295 .000 & 100,0 \\
\hline \multicolumn{4}{c}{ Total }
\end{tabular}

Data pada Tabel 1 menunjukkan bahwa biaya penyusutan kandang adalah biaya yang terbesar $(42,8 \%)$. Biaya penyusutan kendaraan adalah biaya tetap kedua terbesar $(20,7 \%)$. Biaya kandang pada penelitian ini lebih besar dibanding hasil penelitian Ardhani (2006). Hal ini disebabkan karena kandang yang dimiliki Kelompok Tani Ternak sapi "Keong Mas" adalah kandang permanen yang didalamnya juga dibuat menara tempat penyimpanan pakan jerami.

Biaya variabel adalah biaya yang selalu berubah selama proses produksi berlangsung. Unsur - unsur yang termasuk ke dalam biaya variabel yaitu sapibakalan, pakan sapi, obat obatan dan biaya tenaga kerja. Rincian Biaya variabel dapat dilihat pada Tabel 2. 
Tabel 2. Uraian Biaya Variabel Kelompok Tani Ternak Sapi "Keong Mas"

No

1 Pembelian Bakalan Sapi

2 Pakan

3 Obat - Obatan

$4 \quad$ Tenaga Kerja

Uraian
52. 500.000

27. 371.250

600. 000

10. 800.000

91.271. 250

Total

merupakan hasil penjualan ternak sapi dikali dengan harga. Penerimaan yang diperoleh sebesar Rp. 105.000.000 dari hasil penjualan 15 ekor sapi dengan harga Rp. 7.000.000 / ekor.

Tujuan utama dalam pembukaan usaha yang direncanakan adalah memperoleh keuntungan. Keuntungan adalah jumlah rupiah yang diperoleh dari pendapatan bersih suatu usaha. Keuntungan kelompok tani ternak sapi "Keong Mas" diperoleh dari penerimaan dikurangi dengan biaya produksi. Berdasarkan hasil analisis diatas menunjukkan bahwa jumlah ternak sapi sebanyak 15 ekor memperoleh keuntungan sebesar Rp.7.433.750.

Hasil analisis kelayakan usaha penggemukan sapi potong kelompok tani ternak sapi "Keong Mas" menunjukkan nilai NPV sebesar Rp. 38,795,714, IRR $38 \%$ dan Net B/C adalah 1.95. Berdasarkan nilai kriteria 
investasi ini dapat dinyatakan bahwa usaha penggemukan sapi di kelompok “Keong Mas" layak untuk dijalankan. Hal ini ditunjang oleh Kaunang (2008) yang melakukan penelitian di Wilayah SUB DAS Molompar menunjukkan bahwa usaha ternak sapi layak dijalankan dilihat dari nilai NPV, IRR dan BCR. Salendu (2012) menyatakan bahwa usaha ternak sapi dapat dikembangkan dilihat dari kelayakan secara secara finansial.

\section{KESIMPULAN}

Berdasarkan hasil penelitian dapat disimpulkan bahwa :

1. Usaha penggemukan sapi potong yang dilaksanakan oleh kelompok tani "Keong Mas" memperoleh keuntungan positif yaitu sebesar Rp. 7.433.750 dengan jumlah sapi sebanyak 15 ekor yang dipelihara selama 6 bulan.

2. Usaha penggemukan sapi potong layak untuk dijalankan dilihat dari nilai NPV sebesar Rp. 38,795,714, IRR $38 \%$ dan Net B/C adalah 1,95.

\section{SARAN}

Berdasarkan hasil penelitian dapat disarankan bahwa perlu perhatian baik dari anggota kelompok maupun pemerintah dalam mengembangkan usaha penggemukan sapi potong dengan memperhatikan breeding, feeding dan management.

\section{DAFTAR PUSTAKA}

Abidin, Z. 2002. Penggemukan Sapi Potong. Agromedia Pustaka. Jakarta Ardhani, F.2006. Prospek Dan Analisa Usaha Penggemukan Sapi Potong di Kalimantan Timur Ditinjau Dari Sosial Ekonomi. Skripsi. Universitas Mulawarman. Samarinda.

Aries, K. 2008. Metode Penelitian. Bumi Aksara, Jakarta.

Elly, F.H. 2008. Perilaku Ekonomi Rumahtangga Peternak Sapi di Kecamatan Tompaso. Jurnal Zootek. Vol 27 Juli 2008. P: 249-259.

Elly, F.H. 2009. Ternak Sapi dan Prospek Pengembangannya di Kabupaten Minahasa. Jurnal Zootek. Vol 29 Juli 2009. P: 219-232.

Kaunang, W. B. 2008. Analisis Kelayakan Usaha Ternak Sapi di Wilayah SUB DAS Molompar. Jurnal Zootek. Vol. 27. Juli 2009. p. $159-167$.

Kiswanto, A. Prabowo dan Widyantoro. 2004. Transformasi 
Struktur Usaha Penggemukan

Sapi Potong di Lampung

Tengah. Prosiding Seminar.

Sistem Kelembagaan Usahatani

Tanaman-Ternak. Badan

Penelitian dan Pengembangan

Pertanian, departemen

Pertanian. P: 111-121.

Prawirokusumo, S. 2000. Ilmu Usaha

Tani. Penerbit BPFE.

Yogyakarta.

Salendu, A.H. S.dan F. H. Elly. 2009.

Analisis

Kelembagaan

Pemasaran Sapi Potong di

Kabupaten Bolaang

Mongondow Utara. Jurnal

Zootek. Vol. 29. Juli 2009. P.

126-139.

Salendu, A.H.S. 2012. Perspektif Pengelolaan Agroekosistem

Kelapa-Ternak Sapi di

Minahasa Selatan. Disertasi

Doktor. Program Pascasarjana

Fakultas Pertanian Universitas

Brawijaya, Malang.

Soekardono. 2009. Ekonomi

Agribisnis Peternakan, Teori

dan Aplikasinya. Penerbit

Akademika Pressindo, Jakarta.

Suryapratama, W dan D. Santosa.

2011. Penggunaan Daun Turi dan Lamtoro Dalam Pakan Sapi

Potong Yang Berbasis Jerami

Padi Terhadap Produk
Fermentasi Rumen dan

Kecernaan Nutrien Secara in

Vitro. Prosiding Seminar

Nasional. Prospek dan Potensi

Sumberdaya Ternak Lokal

Dalam Menunjang Ketahanan

Pangan Hewani. Fakultas

Peternakan Universitas

Soedirman, Purwokerto. p : 143148.

Yusran, M. A. 2004. Struktur Usaha Penggemukan Sapi Potong di Jawa Timur. Prosiding Seminar.

Sistem Kelembagaan Usahatani

Tanaman-Ternak. Badan

Penelitian dan Pengembangan

Pertanian, departemen

Pertanian. P: 174-201. 
